\title{
ANALISIS KEBUTUHAN: PEMBELAJARAN BERBASIS WEB PADA MAHASISWA VOKASIONAL
}

\author{
Ina Yulianti ${ }^{*}$, Ida Hamidah², Mumu Komaro ${ }^{3}$, Ahmad Mudzakir ${ }^{4}$ \\ ${ }^{123}$ Program Studi Pendidikan Teknologi Kejuruan, Pasca Sarjana Universitas Pendidikan Indonesia (UPI), Indonesia \\ ${ }^{4}$ Program Studi Pendidikan Kimia, Universitas Pendidikan Indonesia (UPI), Indonesia \\ Jl. Dr. Setiabudi No. 229, Bandung, Jawabarat \\ *Corresponding Author: yuliantiina@gmail.com
}

\begin{abstract}
ABSTRAK
Memasuki era digital, teknologi komunikasi dan informasi terus mengalami perkembangan. Oleh karenanya perkembangan teknologi tersebut harus dapat diadop dan dimanfaatkan untuk kepentingan pembelajaran. Ketersediaan bahan ajar di lingkungan sampel yang diteliti masih sangat terbatas, sumber pelajaran yang ada masih berupa referensi lama dan pembelajaran pada umumnya hanya menggunakan power point dengan format yang kurang menarik. Tujuan penelitian ini adalah untuk mengetahui kebutuhan pembelajaran berbasis website bagi mahasiswa vokasional. Sampel penelitian diambil menggunakan teknik Purposive Sampling sebanyak lima orang mahasiswa program studi Teknik Kimia. Pengumpulan data dilakukan dengan metoda wawancara semi terstruktur, observasi tidak terstruktur dan dokumentasi lapangan untuk mengetahui tingkat urgensi kebutuhan bahan ajar berbasis web. Instrumen penelitian adalah peneliti sendiri dengan dibantu pedoman wawancara. Data yang terkumpul kemudian dianalisis dengan menggunakan teori analisis Miles dan Huberman. Berdasarkan hasil triangulasi dari ketiga data tersebut, maka mahasiswa sangat tertarik dengan pembelajaran berbasis web, akan tetapi pembelajaran berbasis web tersebut belum sepenuhnya bisa dilakukan mahasiswa secara mandiri, harus disertai dengan penjelasan dosen secara riil. Penelitan ini diharapkan dapat memberikan rekomendasi kepada pengambil kebijakan untuk dapat memenuhi kebutuhan bahan ajar berbasis web bagi mahasiswa vokasi untuk meningkatkan hasil belajarnya.
\end{abstract}

Kata Kunci: Era Digital, Website, Triangulasi, Purposive Sampling, Teori Analisis

\begin{abstract}
Entering the digital era, communication and information technology continues to experience development. Therefore the development of these technologies must be adopted and utilized for the benefit of learning. The availability of teaching materials in the sample environment studied is still very limited, the existing learning resources are still in the form of old references and learning in general only uses power points with a format that is less attractive. The purpose of this study was to determine the need for website-based learning for vocational students. The research sample was taken using Purposive Sampling as many as five Chemical Engineering students. Data collection is done by semi-structured interview methods, unstructured observation and field documentation to determine the urgency level of web-based teaching material needs. The research instrument was the researcher herself, assisted by interview guidelines. The collected data is then analyzed using Miles and Huberman's analysis theory. Based on the triangulation of the three data, students are very interested in web-based learning, but web-based learning cannot be done independently by students, it must be accompanied by a real teacher explanation. This research is expected to provide recommendations to policy makers to be able to meet the needs of web-based teaching materials for vocational students to improve their learning outcomes.
\end{abstract}

Keywords: Digital Era, Website, Triangulation, Purposive Sampling, Analytical Theory

JTIP@Attribution-ShareAlike 4.0 International License

PENDAHULUAN

Penggunaan internet atau "www" (world wide web) sebagai sumber informasi, menyediakan platform yang beragam untuk pembelajaran dan menawarkan situs yang dapat digunakan untuk berbagai tujuan. Web atau website telah menjadi 
bagian integral dalam kehidupan. Para pendidik dapat memanfaatkan potensi web ini secara efektif untuk mendukung pembelajaran [1]. Dosen diharapkan dapat menciptakan pembelajaran yang menarik dengan memanfaatkan teknologi informasi yang semakin canggih ini [2].

Web mulai tersedia secara luas pada awal hingga pertengahan tahun 1990-an dan dengan cepat menggantikan email sebagai media internet pilihan karena mudah digunakan [3]. Menyediakan kolaborasi responden, dan menyediakan kemungkinan multimedia dan survei interaktif yang mengandung audio dan video [4]. Web menawarkan kenyamanan untuk mengetahui alamat email responden [5]. WWW sebagai perangkat lunak telah berhasil dirancang untuk memenuhi kebutuhan aplikasi hypermedia skala Internet [6].

Salah satu contoh penelitian penggunaan web dalam pembelajaran adalah penelitian yang berjudul, "The effect of web-based learning in pediatric basic life support (P-BLS) training", hasil penelitian ini menunjukkan bahwa penggunaan video klip berbasis web dapat meningkatkan proses pembelajaran dengan kinerja hasil yang lebih baik dibandingkan dengan metoda pembelajaran tradisional [7]. Contoh lainnya adalah penelitian yang berhubungan dengan perancangan/ pengembangan Web sebagai media pembelajaran yaitu penelitian dengan judul, "Comparison of Traditional and Web-Based Medical Student Teaching by Radiology Residents", menghasilkan temuan evaluasi secara acak dan terkontrol terhadap intervensi kurikulum radiologi baru berbasis web, dengan menunjukkan skor tes yang lebih baik dibandingkan dengan metode pengajaran tradisional [8].

Mengacu pada hasil kajian dari beberapa literatur tersebut, serta semakin pesatnya perkembangan informasi dan teknologi sekarang, maka perlu dilakukan inovasi pembelajaran dengan mengembangkan bahan ajar berbasis web sebagai media pembelajaran [9]. Hal ini diharapkan supaya mahasiswa menjadi lebih tertarik untuk belajar dan pemahaman /kompetensinya dapat lebih meningkat, menjadi lebih termotivasi untuk bisa belajar secara mandiri (individual learning style) [10].

\section{Pembelajaran Berbasis Website}

Pembelajaran berbasis website merupakan suatu pembelajaran yang bisa diakses melalui jaringan internet. Pembelajaran berbasis web yang populer dengan sebutan Web Based Traning (WBT) atau disebut Web Based Education (WBE) dapat didefinisikan sebagai aplikasi teknologi web dalam dunia pembelajaran untuk sebuah proses pendidikan [11]. Pembelajaran berbasis web memerlukan sebuah model instruktur yang dirancang khusus untuk keperluan pembelajaran. Web dapat menciptakan sebuah lingkungan belajar maya (Virtual Learning Environment) [12]. Lingkungan belajar yang disediakan oleh web dilengkapi dengan beberapa fasilitas yang dapat kita kombinasikan penggunaannya untuk mendukung proses pembelajaran, seperti video, teks materi pembelajaran, lembar kerja siswa yang dapat dikerjakan secara simulasi interaktif, penilaian online, dan sistem administrasi. Yang menarik dari penggunaan $w e b$, yaitu dilengkapinya hyperlink yang memungkinkan untuk mengakses informasi lebih luas [13].

Prinsip utama dalam pelaksanaan pembelajaran berbasis web adalah harus adanya interaksi atau komunikasi antar peserta, maupun instruktur dalam lingkungan belajar [14]. Kemudian harus ada ketergunaan yaitu bagaimana perkembangan pembelajaran berbasis web ini menciptakan lingkungan belajar yang konsisten dan sederhana, sehingga mahasiswa tidak mengalami kesulitan dalam proses pembelajaran dan juga harus ada relevansi setiap informasi yang spesifik untuk meningkatkan pemahaman mahasiswa dan menghindari bias. Pembelajaran berbasis web melibatkan banyak pihak seperti pengguna, autor, pendidik, penilai, operator, teknisi dan lain-lain.

Pembelajaran berbasis web memiliki keuntungan yaitu:

1) Siswa menjadi bagian dari pelajaran; teknologi web memberikan kesempatan pada siswa untuk menjadi bagian dan berkontribusi secara aktif dalam pelajaran di kelas. Tekniknya bisa dengan membuat akun terlebih dahulu;

2) Dunia Menjadi Kelas; Teknologi web memperluas ruang kelas menuju dunia virtual. Pelajaran bisa terbuka untuk siapa saja, tidak terbatas pada satu ruang kelas. Siswa dapat dengan mudah bekerja melintasi batas budaya, nilai, dan minat yang berbeda, sehingga siswa memiliki perspektif yang lebih global;

3) Kolaborasi dan persaingan meningkatkan pembelajaran; Teknologi web memiliki aspek kolaborasi dan persaingan yang memungkinkan siswa untuk bekerja bersama, atau bersaing satu sama lain dalam proyek;

4) Ruang kelas tersedia 24/7; Teknologi Web berbasis Internet, menyediakan waktu 24 jam sehari, 7 hari seminggu. Siswa hanya memerlukan koneksi internet dan dapat berada di kelas. Setelah selesai belajar melalui internet/web, siswa dapat saling berinteraksi di lingkungan kelas. 
Sedangkan kekurangan pembelajaran berbasis web yaitu:

1) Keterbatasan akses internet; pada umumnya siswa menggunakan akses internet di area kampus akan tetapi tidak semua siswa memiliki akses internet di luar area kampus;

2) Sabotase web; Pekerjaan seseorang dapat disabotase oleh orang lain, karena pekerjaan tersebut dapat terlihat oleh siapapun;

3) Plagiarisme; Di dunia on line plagiarisme sangat mudah, seperti mencari jawaban yang cepat untuk setiap pertanyaan dan tugas dapat menjadi plagiarism;

4) Tingkat Keterbukaan; Dalam teknologi web, tugas dan tanggapan tertulis tidak lagi hanya melibatkan profesor dan mahasiswa, tetapi tersedia bagi siapa saja untuk dilihat dan dievaluasi. Keterbukaan ini menyebabkan ketidaknyamanan bagi beberapa mahasiswa [15].

\section{Pengumpulan Data}

Penelitian kualitatif yang berkaitan dengan manusia melibatkan tiga jenis pengumpulan data, yaitu; wawancara mendalam dan terbuka, observasi langsung, dan dokumen tertulis [16].

\section{Wawancara}

Wawancara adalah proses komunikasi atau interaksi untuk mengumpulkan informasi dengan cara tanya jawab antara peneliti dengan informan/responden. Supaya wawancara lebih efektif, maka sebaiknya melalui tahapan; mengenalkan diri, menjelaskan maksud kedatangan, menjelaskan materi wawancara, dan mengajukan pertanyaan. Terdapat dua jenis wawancara, yaitu:

a) wawancara mendalam (in-depth interview), dimana peneliti menggali informasi secara mendalam dengan cara terlibat langsung dengan kehidupan informan [17]. Tanya-jawab secara bebas tanpa pedoman pertanyaan yang disiapkan sebelumnya sehingga suasananya lebih hidup, dan dapat dilakukan berkali-kali;

b) wawancara terarah (guided interview), dimana peneliti menanyakan kepada informan hal-hal yang telah disiapkan sebelumnya [18].

Berkat kemajuan teknologi informasi, wawancara dapat dilakukan tanpa tatap muka langsung tetapi dapat melalui media komunikasi, seperti wawancara elektronik yang merupakan alternatif lain selain wawancara tradisional [19]. Metode ini dapat digunakan, untuk menguji sikap, pendapat, kepercayaan, dan pengalaman individu dalam penelitian. Wawancara dapat dilakukan secara bersamaan atau sebaliknya. Pewawancara berkomunikasi dengan orang yang diwawancarai secara bersamaan seperti pada percakapan telepon, video-call, penggunaan webcam, dan mengobrol di jejaring sosial. Wawancara dapat dilakukan dalam waktu yang berbeda (ansinkron) seperti dalam surel, komunitas daring, dan papan buletin atau situs jejaring social [20].

Wawancara elektronik bermanfaat untuk mengatasi kesulitan ruang dan waktu seperti pada perkuliahan jarak jauh, wawancara dengan orangorang yang sulit diakses, wawancara berkenaan dengan kenyamanan, terkait efektivitas biaya, serta dapat menyimpan informasi dengan mudah dan cepat. Keterbatasan wawancara elektronik diantaranya kurangnya perhatian dan konsentrasi peserta, ketidakmampuan untuk menggunakan teknologi, akses internet yang tidak mencukupi.

\section{Observasi}

Observasi adalah jenis metode penelitian kualitatif yang tidak hanya mencakup pengamatan peserta, tetapi juga mencakup etnografi dan pekerjaan penelitian di lapangan. Observasi dilakukan untuk memperoleh gambaran rill suatu peristiwa atau kejadian yang diperlukan untuk menjawab pertanyaan penelitian. Data pengamatan dapat diintegrasikan sebagai penelitian tambahan atau konfirmasi. Ada dua metoda observasi dalam penelitian yaitu terstruktur dan tidak terstruktur. Pemilihan metoda ini bergantung pada paradigma yang mendasari setiap penelitian [21].

\section{Dokumentasi}

Studi dokumen menjadi metode pelengkap bagi penelitian kualitatif dalam teknik pengumpulan data. Tidak semua dokumen memiliki kredibilitas yang tinggi, sehingga harus selektif dan hati-hati dalam penggunaannya. Dokumen sebagai sumber data banyak dimanfaatkan oleh para peneliti, terutama untuk menguji, menafsirkan dan bahkan untuk meramalkan. Studi dokumen berguna bagi penelitian kualitatif, karena merupakan sumber yang stabil, kaya data, berguna sebagai bukti untuk suatu pengujian, berguna dan sesuai karena sifatnya yang alamiah, sesuai dengan konteks, relatif murah dan tidak sukar ditemukan tetapi membutuhkan waktu untuk mempelajarinya, hasil pengkajian isi akan membuka kesempatan untuk lebih memperluas pengetahuan.

Penelitian ini merupakan studi pendahuluan terhadap analisis kebutuhan pembelajaran berbasis web pada salah satu politeknik swasta. Pengumpulan data dilakukan menggunakan teknik wawancara semi terstruktur [22] observasi lapangan/observasi tidak terstruktur [21], dan 
dokumentasi lapangan sebagai pelengkap data penelitian. Peneliti sendiri bertindak sebagai instrumen penelitian. Pedoman penelitian, berupa pertanyaan- pertanyaan terstruktur sebanyak 10 buah ditunjukkan oleh Tabel 1, digunakan untuk menggali informasi mahasiswa terkait kondisi pembelajaran dan lingkungan belajar yang menjadi objek penelitian.

Tabel 1. Pedoman Wawancara

\begin{tabular}{cl}
\hline No & \multicolumn{1}{c}{ Deskripsi Pertanyaan } \\
\hline 1 & $\begin{array}{l}\text { Selama ini materi kuliah disajikan dalam bentuk } \\
\text { apa? }\end{array}$ \\
2 & $\begin{array}{l}\text { Bentuk bahan ajar seperti apa yang diinginkan? } \\
3\end{array}$ \\
$\begin{array}{l}\text { Pembaharuan apa yang diharapkan supaya } \\
\text { pembelajaran dapat berlangsung efektif dan efisien }\end{array}$ \\
serta mudah dipahami?
\end{tabular}

\section{METODE}

Informasi data dari hasil wawancara dengan mahasiswa, diperkuat dengan observasi peneliti secara tidak terstruktur dan dokumentasi yang ada dilapangan sebagai penunjang penelitian [23]. Sampel diambil dengan teknik purposive sampling [24], adalah mahasiswa vokasional teknik kimia sebanyak lima orang yang diwawancarai secara indivual di awal dan secara berkelompok di akhir wawancara [25].

Data yang terkumpul, kemudian dianalisis dengan menggunakan teori analisis data Miles dan Huberman dengan tahapan seperti diperlihatkan oleh Gambar 1 [26]. Berdasarkan tahapan analisis Data yang ditunjukkan oleh Gambar 1:

1. Tahap Analisis atau Pengumpulan Data;

Proses analisis pengumpulan data dimaksudkan untuk memperoleh informasi yang dibutuhkan dalam mencapai tujuan penelitian. Data awal merupakan data hasil wawancara individu dan kelompok.

\section{Tahap Reduksi;}

Tahap ini dilakukan dengan merangkum, memilih hal-hal yang pokok, memfokuskan pada hal-hal

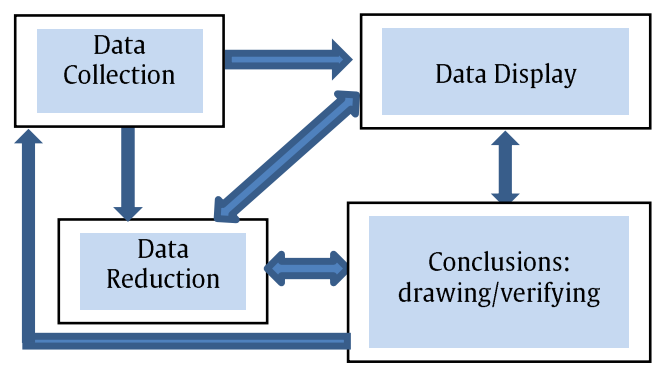

Gambar 1. Tahap Analisis Data [26]

yang penting, mencari tema dan polanya. Seperti meringkas data, pengkodean, pembuatan catatan obyektif, membuat catatan reflektif, membuat catatan, marginal, penyimpanan data.

3. Tahap Penyajian;

Penyajian data dalam bentuk teks narasi atau tabel dilakukan untuk memudahkan pemahaman terhadap apa yang terjadi dan merencanakan kerja selanjutnya. Pada tahapan ini dikembangkan model-model mendeskripsikan konteks dalam penelitian, cheklist matriks, mendeskripsikan perkembangan antar waktu, matriks tata peran, matriks konsep terklaster, matriks efek dan pengaruh, matriks dinamika lokasi dan daftar kejadian.

4. Tahap penarikan kesimpulan dan verifikasi data; Pada tahap ini dilakukan penarikan kesimpulan.

Dalam penelitian kualitatif kesimpulan dapat menjawab rumusan masalah yang dirumuskan sejak awal, tetapi mungkin juga tidak dapat menjawab rumusan masalah. Kesimpulan awal yang dikemukakan dapat bersifat sementara, jika masih mengalami perubahan saat pengumpulan data berikutnya dan dapat bersifat kredibel jika sudah didukung bukti yang valid dan konsisten. Oleh karena itu data yang sudah disimpulkan tadi selanjutnya di uji keabsahannya dengan dibandingkan terhadap data lain supaya terjamin keabsahannya melalui Triangulasi data seperti diperlihatkan oleh Gambar 2.

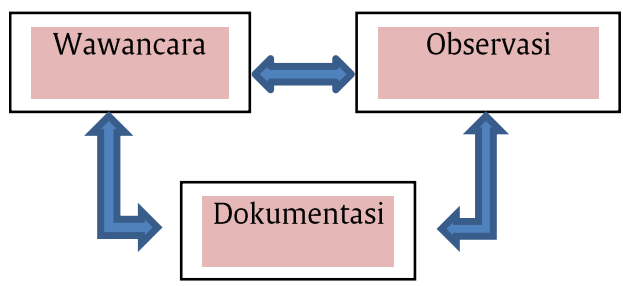

Gambar 2. Triangulasi Data [27]

Triangulasi mengacu pada penggunaan lebih dari satu pendekatan dalam menjawab pertanyaan 
penelitian untuk meningkatkan kepercayaan pada temuan berikutnya. Tujuan utama triangulasi adalah untuk meningkatan dan menunjukkan keandalan temuan penelitian. Empat bentuk triangulasi meliputi : triangulasi data, triangulasi peneliti, triangulasi teoretis, dan triangulasi metodologis [28]. Triangulasi data mengacu pada penggunaan berbagai sumber data seperti data wawancara, observasi, dan dokumentasi. Dalam Triangulasi peneliti, seorang peneliti membiarkan peneliti lain berpartisipasi untuk mengumpulkan dan menafsirkan data. Triangulasi teoretis menggambarkan penggunaan lebih dari satu posisi teoretis ketika menafsirkan. Triangulasi data metodologi mengacu pada penggunaan lebih dari satu metode penelitian.

\section{HASIL DAN PEMBAHASAN}

Data yang diperoleh dari hasil wawancara semi terstruktur untuk kelima informan dan kelompok melalui 10 item pertanyaan diperlihatkan oleh Tabel 2. Data wawancara tersebut didukung oleh data hasil observasi langsung peneliti terhadap kondisi pembelajaran serta lingkungan belajar yang diperlihatkan oleh Tabel 3.

Tabel 2. Hasil Wawancara Individu dan Kelompok

\begin{tabular}{|c|c|c|c|c|c|c|}
\hline No. & Informan Kelompok & Informan A & Informan B & Informan C & Informan D & Informan E \\
\hline 1 & Ppt & In & Ppt & Ppt & Ppt & Ppt \\
\hline 2 & On line & Ebook & Website & On line & Ebook & Internet \\
\hline 3 & Metoda pembelajaran & $\begin{array}{l}\text { Metoda } \\
\text { pembelajaran }\end{array}$ & E earning & $\begin{array}{l}\text { Lebih } \\
\text { konstektual }\end{array}$ & $\begin{array}{l}\text { Lebih } \\
\text { konkrit }\end{array}$ & Lebih kontektual \\
\hline 4 & Internet & Ppt/ebook & Website/aplikasi & $\begin{array}{l}\text { On line, } \\
\text { animasi }\end{array}$ & Video & $\begin{array}{l}\text { Website, studi } \\
\text { lapangan }\end{array}$ \\
\hline 5 & Tempat informasi & Media informasi & $\begin{array}{l}\text { Kumpulan } \\
\text { informasi }\end{array}$ & Tempat iptek & $\begin{array}{l}\text { Situs } \\
\text { informasi }\end{array}$ & Alamat informasi \\
\hline 6 & Ada & Tersedia & Ada & Tersedia & Ada & Ada \\
\hline 7 & Dapat membantu & Ya & Dapat membntu & Membantu & $\begin{array}{l}\text { Sangat } \\
\text { membantu }\end{array}$ & Dapat membantu \\
\hline 8 & Web dan ceramah & Web & Web & Ceramah & $\begin{array}{l}\text { Web dan } \\
\text { ceramah }\end{array}$ & Web \\
\hline 9 & Mudah di akses & Ilmu luas & Tidak terbatas & Mudah diakses & $\begin{array}{l}\text { Mudah } \\
\text { dicari }\end{array}$ & $\begin{array}{l}\text { Lebih bisa } \\
\text { mengeksplor }\end{array}$ \\
\hline 10 & Kuota/wifi & Kuota/wifi & Kuota/batre & $\begin{array}{l}\text { Informasi } \\
\text { terkadang } \\
\text { tidak jelas }\end{array}$ & Miskonsepsi & $\begin{array}{l}\text { Adanya iklan, } \\
\text { tulisan tidak jelas }\end{array}$ \\
\hline
\end{tabular}

Tabel 3. Data observasi lapangan

\begin{tabular}{|c|c|}
\hline Kategori & Pengamatan \\
\hline Pembelajaran & $\begin{array}{l}\text { Sudah terpusat di mahasiswa } \\
\text { Menggunakan power point }\end{array}$ \\
\hline Akses Internet & Memadai \\
\hline $\begin{array}{l}\text { Aktivitas } \\
\text { mahasiswa dalam } \\
\text { pembelajaran }\end{array}$ & $\begin{array}{l}\text { Menggali informasi melalui } \\
\text { internet dan presentasi }\end{array}$ \\
\hline Sumber belajar & Internet \\
\hline Perpustakaan & $\begin{array}{l}\text { Tersedia buku cetak dan jurnal } \\
\text { internal terindeks google } \\
\text { scholar }\end{array}$ \\
\hline Laboratorium & Belum memadai \\
\hline Penelitian & Masih terbatas \\
\hline
\end{tabular}

dan data dokumentasi situasi pembelajaran yang ditunjukkan sebagai penunjang pembelajaran, diperlihatkan oleh Tabel 4.

Tabel 4. Data Dokumentasi Lingkungan Belajar

\begin{tabular}{|c|c|}
\hline Kategori & Pengamatan \\
\hline Silabus & $\begin{array}{l}\text { Konten dan konsep lama } \\
\text { Referensi lama }\end{array}$ \\
\hline RPS & $\begin{array}{l}\text { Tidak mengaitkan antara aspek } \\
\text { pengetahuan, ketrampilan dan sikap }\end{array}$ \\
\hline Buku sumber & $\begin{array}{l}\text { Sangat terbatas, tidak variatif } \\
\text { Kebanyakan berupa fotocopy yg dicover } \\
\text { Tersedia buku cetak }\end{array}$ \\
\hline Perpustakaan & Jurnal internal terideks google scholar \\
\hline Bahan Ajar & Power point (Ppt) \\
\hline
\end{tabular}


Pengumpulan Data hasil wawancara kelima informan dan kelompok, kemudian direduksi menurut pemikiran peneliti sehingga lebih ringkas dan tersaji pada Tabel 2, kemudian disimpulkan dalam respon mahasiswa seperti ditunjukkan oleh Tabel 5.

Tabel 5. Respon Mahasiswa

\begin{tabular}{|c|c|c|}
\hline No & Deskripsi pertanyaan & Respon mahasiswa \\
\hline 1 & $\begin{array}{l}\text { Selama ini materi kuliah } \\
\text { disajikan dalam bentuk apa? }\end{array}$ & $\begin{array}{l}\text { Banyak menggunakan } \\
\text { PPT }\end{array}$ \\
\hline 2 & $\begin{array}{l}\text { Bentuk bahan ajar seperti apa } \\
\text { yang diinginkan? }\end{array}$ & $\begin{array}{l}\text { On line, ebook, } \\
\text { website, internet }\end{array}$ \\
\hline 3 & $\begin{array}{l}\text { Pembaharuan apa yang } \\
\text { diharapkan supaya } \\
\text { pembelajaran dapat } \\
\text { berlangsung efektif dan efisien } \\
\text { serta mudah dipahami? }\end{array}$ & $\begin{array}{l}\text { Metoda pembelajaran, } \\
\text { e-learning, kontekstual }\end{array}$ \\
\hline 4 & Apakah website? & Situs informasi \\
\hline 5 & $\begin{array}{l}\text { Darimana sumber } \\
\text { pembelajaran diperoleh, selain } \\
\text { dari penjelasan dosen? }\end{array}$ & $\begin{array}{l}\text { Internet, ppt, ebook, } \\
\text { Website,aplikasi, } \\
\text { online animasi, video - }\end{array}$ \\
\hline 6 & $\begin{array}{l}\text { Apakah kebutuhan internet } \\
\text { tersedia? }\end{array}$ & Tersedia \\
\hline 7 & $\begin{array}{l}\text { Apakah pembelajaran berbasis } \\
\text { web, dapat membantu } \\
\text { pemahaman? }\end{array}$ & Dapat membantu \\
\hline 8 & $\begin{array}{l}\text { Manakah yang lebih efektif, } \\
\text { pembelajaran ceramah oleh } \\
\text { dosen, atau pembelajaran } \\
\text { menggunakan web? }\end{array}$ & Web dan ceramah \\
\hline 9 & $\begin{array}{l}\text { Apakah keuntungan/kelebihan } \\
\text { belajar menggunakan web, jika } \\
\text { dibandingkan dengan media } \\
\text { pembelajaran lainnya? }\end{array}$ & $\begin{array}{l}\text { Mudah diakses, lebih } \\
\text { mengekplor }\end{array}$ \\
\hline 10 & $\begin{array}{l}\text { Apakah kekurangan } \\
\text { pembelajaran berbasis web?. }\end{array}$ & $\begin{array}{l}\text { Kuota, batre, informasi } \\
\text { tidak jelas. }\end{array}$ \\
\hline
\end{tabular}

Berdasarkan data yang terkumpul dari seluruh informan baik individual atau kelompok, untuk pertanyaan nomor 1 , semua informan menjawab bahan ajar ditransformasikan dalam bentuk power point. Untuk pertanyaan nomor 2, hampir semua mahasiswa menjawab sumber pelajaran yang diharapkan berupa on line, ebook, website, internet. Penggunaan power point sekalipun, konsep/materinya diambil dari situs tertentu melalui internet. Jawaban pertanyaan nomor 3, pada umumnya metoda pembelajaran yang diharapkan adalah pembelajaran e-learning, kontekstual lebih pada praktek di lapangan. Sumber pelajaran dapat diperoleh melalui internet, power point (ppt), ebook, website, aplikasi, on line animasi, video (jawaban pertanyaan No. 4). Semua informan mengetahui yang dimaksud website dan dapat menjelaskan definisi website (jawaban pertanyaan
No. 5). Tersedia fasilitas internet dan cukup memadai (jawaban No. 6). Untuk jawaban pertanyaan nomor 7, pembelajaran berbasis web dapat membantu pemahaman siswa dalam mengeksplor pengetahuan terkait pembelajaran dan penelitian. Sebagian mahasiswa menjawab, pembelajaran ceramah dan berbasis web, keduanya dapat berlangsung efektif apabila keduanya dapat saling mengisi dan melengkapi (jawaban No. 8). Satu orang mahasiswa berpendapat bahwa pembelajaran berbasis web dapat dipadukan dengan penjelasan dosen sebagai penguatan terhadap konsep/materi yang belum jelas. Tiga orang mahasiswa lebih menginginkan pembelajaran yang interaktif berbasis on line, website, selain dari penjelasan dosen, sedangkan satu orang berpendapat bahwa pembelajaran cukup dengan penjelasan dosen di kelas dengan menggunakan power point asalkan kompetensi dosen dapat terukur. Penjelasan dosen dikelas dapat divariasikan dengan melibatkan mahasiswa seperti dalam metode diskusi, tanya jawab, kerja kelompok dan presentasi [29]. Pembelajaran berbasis web dan catatan penjelasan dosen keduanya memungkinkan untuk dapat digunakan, [30]. Pembelajaran langsung dengan dosen di kelas sangat dibutuhkan dengan ditunjang oleh media pembelajaran yang menarik dan mudah dipahami. Kebutuhan bahan ajar yang ada diinternet atau dalam bentuk informasi pada website dimaksudkan untuk memperkuat pemahaman mahasiswa.

Untuk menjawab pertanyaan nomor 9, keuntungan/kelebihan pembelajaran menggunakan web menurut mahasiswa yaitu semua menjawab kemudahan mengakses, searching explore banyak pilihan sumber, mendapatkan ilmu yang lebih luas, banyak hal yang baru, tidak semua dosen menjelaskan informasi sedetil informasi di web. Sedangkan kekurangan pembelajaran berbasis web yaitu, keterbatasan kuota apabila tidak ada wifi, kurangnya interaksi langsung antara dosen dengan mahasiswa, baterai yang sering ngedrop, dan informasi yang kurang jelas misalnya dengan muncul huruf atau angka yang kurang sesuai, serta banyaknya iklan yang menutupi konten (jawaban soal No. 10).

Observasi terhadap lingkungan belajar, diperoleh hasil seperti ditunjukkan oleh Tabel 3. 
Hal ini memberikan gambaran sejumlah kelemahan-kelemahan yang harus diperbaharui seperti pembelajaran masih mengandalkan power point, perpustakaan yang tidak on line. RPS, silabus dan buku sumber masih berupa paper. Kelemahankelemahan tersebut harus diperbaiki dengan melaksanakan pembelajaran berbasis informasi dan teknologi, menggunakan dan mencari penyelesaian solusi menggunakan media internet sebagai big data. Akses internet sudah memadai maka pembelajaran dapat dilakukan secara on line dengan menampilkan situs-situs menarik yang berisi video, animasi, praktek virtual, simulasi interaktif, dan penilaian on line [31]. Administrasi pembelajaran juga seharusnya sudah dapat diakses melalui web. Aktivitas mahasiswa semester lima program studi diploma tiga teknik kimia dalam pembelajaran sudah mulai terpusat pada mahasiswa seiring dengan pencarian informasi dari internet terkait tugas akhir. Ketersediaan buku-buku atau jurnal masih sangat terbatas di perpustakaan, namun sudah ada jurnal elektronik internal politeknik yang terindeks google scholar. Laboratorium belum memadai karena kurang tersedianya alat dan bahan yang diperlukan, sehingga kebutuhan pembelajaran berbasik web dan kebutuhan praktikum secara virtual berbasis web atau simulasi elektronik sangat mendesak [32]. Informasi data dokumentasi pada Tabel 4, masih perlu dilakukan pembenahan terhadap dokumen kurikulum terutama terkait silabus yang masih berisi konsep lama. Kompetensi aspek pengetahuan, keterampilan dan sikap [33] tidak tersurat dengan jelas. Tidak ada perbedaan ketercapaian keterampilan umum dan keterampilan khusus yang harus dicapai, juga tidak mengedepankan aspek sikap. Metoda pembelajaran masih bersifat konvensional dengan daftar pustaka versi lama. Capaian pembelajaran lulusan program studi yang dibebankan pada matakuliah sudah berbeda dengan capaian pembelajaran matakuliah tiap dosen. Dokumentasi bahan ajar, hanya sebatas kumpulan powerpoint yang kurang interaktif dan soal-soal yang diujikan masih bersifat paper test sehingga hasil tes menjadi kurang objektif, karena mahasiswa dimungkinkan masih bisa bekerjasama dengan yang lainnya ketika tes. Buku sumber kurang variatif, penggunaan perpustakaan kurang efektif, oleh karenanya pembelajaran berbasis web sangat tepat digunakan sebagai media pembelajaran supaya mahasiswa dapat memaksimalkan belajarnya secara mandiri (individual learning) [34], efektif dan efisien. Triangulasi data [27] dari ketiga metoda pengumpulan data yang dilakukan melalui wawancara, observasi, dan dokumentasi menghasilkan informasi tingkat urgensi yang sama yaitu untuk dapat digunakan media pembelajaran berbasis website dalam upaya untuk memenuhi kebutuhan bahan ajar dan untuk peningkatan hasil belajar mahasiswa vokasional.

\section{KESIMPULAN}

Berdasarkan hasil uji analisis triangulasi wawancara semi terstruktur terhadap lima orang mahasiswa program studi teknik kimia, observasi langsung terhadap lingkungan belajar, dan dokumentasi pembelajaran yang ada di lingkungan politeknik, melihat dari peluang yang ada dan kebutuhan yang urgen, maka sangat perlu dibuatkan bahan ajar berbasis web. Tersedianya akses internet, menjadikan bahan ajar tersebut dapat digunakan secara online. Terbatasnya fasilitas laboratorium maka praktikum dapat dirancang secara virtual interaktif berbasis web. Pengembangan bahan ajar berbasis web ini diharapkan dapat memenuhi kebutuhan bahan ajar sehingga dapat meningkatkan hasil belajar.

\section{SARAN}

Sangat disarankan untuk membuat bahan ajar yang interaktif, seperti membuat simulasi interaktif atau merancang praktikum virtual untuk mengantisipasi terbatasnya alat bahan.

\section{DAFTAR PUSTAKA}

[1] O. Marques, "The world wide web," in SpringerBriefs in Computer Science, 2016.

[2] R. Halstead-Nussloch, C. Dickson, K. Greer, S. Siddiqui, and R. D. Tumuluri, "Recursive online class: Advanced web application class prototypes online educational resources," in ACMSE 2019 - Proceedings of the 2019 ACM Southeast Conference, 2019.

[3] A. Lerner, T. Kohno, and F. Roesner, "Rewriting History: Changing the archivedweb from the present," in Proceedings of the ACM Conference on 
Computer and Communications Security, 2017.

[4] T. Bracamonte, B. Bustos, B. Poblete, and T. Schreck, "Extracting semantic knowledge from web context for multimedia IR: a taxonomy, survey and challenges," Multimed. Tools Appl., 2018.

[5] A. Sendelbah, V. Vehovar, A. Slavec, and A. Petrovčič, "Investigating respondent multitasking in web surveys using paradata," Comput. Human Behav., 2016.

[6] S. Mayer, A. Ciortea, A. Ricci, M. I. Robles, M. Kovatsch, and A. Croatti, "Hypermedia to connect them all: Autonomous hypermedia agents and socio-technical interactions," Internet Technol. Lett., 2018.

[7] M. E. Aksoy, F. Guven, M. E. Sayali, and D. Kitapcioglu, "The effect of web-based learning in pediatric basic life support (P-BLS) training," Comput. Human Behav., 2019.

[8] A. El-Ali, F. Kamal, C. L. Cabral, and J. H. Squires, "Comparison of Traditional and Web-Based Medical Student Teaching by Radiology Residents," J. Am. Coll. Radiol., 2019.

[9] M. Hernandez-de-Menendez and R. MoralesMenendez, "Technological innovations and practices in engineering education: a review," Int. J. Interact. Des. Manuf., 2019.

[10] S. Ginosar, A. Bar, G. Kohavi, C. Chan, A. Owens, and J. Malik, "Learning Individual Styles of Conversational Gesture," 2020.

[11] Rusman, "Model-model Pembelajaran Mengembangkan Profesionalisme Guru," in Jakarta: Rajawali Pers, 2012.

[12] W. A. R. W. M. Isa, A. I. H. Suhaimi, N. Noordin, and N. A. Othman, "3D virtual learning environment," Int. J. Eng. Adv. Technol., 2019.

[13] H. Taneja, "Mapping an audience-centric World Wide Web: A departure from hyperlink analysis," New Media Soc., 2017.

[14] J. Chen, J. Xu, T. Tang, and R. Chen, "WebIntera-classroom: an interaction-aware virtual learning environment for augmenting learning interactions," Interact. Learn. Environ., 2017.

[15] A. L. Harris and A. Rea, "Web 2.0 and Virtual World Technologies: A Growing Impact on IS Education," J. Inf. Syst., 2009.

[16] M. Q. Patton, "Enhancing the qualitative and credibility of qualitative studies," in Qualitative research \& evaluation methods, 2015.

[17] N. M. Deterding and M. C. Waters, "Flexible Coding of In-depth Interviews," Sociol. Methods Res., 2018.

[18] L. S. Borgmann, J. Waldhauer, M. Bug, T. Lampert, and C. Santos-Hövener, "Improving access to migrant populations for epidemiological research-guided interviews with German experts," Bundesgesundheitsblatt - Gesundheitsforsch. - Gesundheitsschutz, 2019.

[19] A. Fontana and A. H. Prokos, "Unstructured Interviewing, Type of Unstructured Interviewing, Ethical Considerations," in The Interview, from Formal to Postmodern, 2016, pp. 39-48, 49-67, 77-81.

[20] I. N. K. Wardana, "Teknik Antarmuka Secara Serial Peripheral Interface ( Spi ) Menggunakan Platform Arduino Dan Matlab," J. Matrix, 2016.

[21] B. S. Brennen, "Ethnography and Participant Observation," in Qualitative Research Methods for Media Studies, 2018.

[22] A. Galletta and W. E. Cross, Mastering the Semi-Structured Interview and Beyond. 2016.

[23] V. Schoeb and A. Hiller, "The impact of documentation on communication during patient-physiotherapist interactions: A qualitative observational study," Physiother. Theory Pract., 2018.

[24] L. J. Wu Suen, H. M. Huang, and H. H. Lee, "A comparison of convenience sampling and purposive sampling," J. Nurs., 2014.

[25] R. A. Krueger and M. A. Casey, "Focus Group Interviewing," in Handbook of Practical 
Program Evaluation: Fourth Edition, 2015.

[26] A. Huberman and M. Miles, The Qualitative Researcher's Companion. 2012.

[27] N. Carter, D. Bryant-Lukosius, A. DiCenso, J. Blythe, and A. J. Neville, "The Use of Triangulation in Qualitative Research," Oncol. Nurs. Forum, 2014.

[28] P. Fusch, G. Fusch, and L. Ness, "Denzin's Paradigm Shift: Revisiting Triangulation in Qualitative Research," J. Soc. Chang., 2018.

[29] A. Pennisi and A. Falzone, "Presentation," in Perspectives in Pragmatics, Philosophy and Psychology, 2020.

[30] J. Parong and R. E. Mayer, "Learning science in immersive virtual reality," J. Educ. Psychol., 2018.

[31] K. Mccutcheon, M. Lohan, M. Traynor, and D. Martin, "A systematic review evaluating the impact of online or blended learning vs. face- to-face learning of clinical skills in undergraduate nurse education," J. Adv. Nurs., 2015.

[32] D. Jie, "Simulation software applied in electronic technology teaching," in Proceedings of the 2012 International Conference on Industrial Control and Electronics Engineering, ICICEE 2012, 2012, pp. 925-927.

[33] M. Kunter, U. Klusmann, J. Baumert, D. Richter, T. Voss, and A. Hachfeld, "Professional competence of teachers: Effects on instructional quality and student development," J. Educ. Psychol., 2013.

[34] D. An and M. Carr, "Learning styles theory fails to explain learning and achievement: Recommendations for alternative approaches," Personality and Individual Differences. 2017. 